\title{
Considerations on the economic effect of the new Turkish commercial code provisions regarding single member companies
}

\author{
Aslı E. Gürbüz Usluel ${ }^{1}$
}

Published online: 10 September 2015

(c) Springer Science+Business Media New York 2015

\begin{abstract}
This article deals with both legal and economic analysis of the new Turkish Commercial Code provisions regarding single member companies. In this respect, legal provisions of the Turkish Commercial Code are examined and compared not only with the Twelfth European Union Directive and Societas Unius Personae, but also regulations of the European Union member states. Since single member companies are to be established as limited liability companies under Turkish law, this article considers the benefits of the limited liability form that can be applied to single member companies in the framework of firm theory. It also examines the benefits and risks of single member companies in terms of transaction costs and assesses the safeguards against the risks in this regard. Finally, an evaluation is made in the light of the data collected relating to the number of companies established after the new Turkish Commercial Code entered into force.
\end{abstract}

Keywords Single member company $\cdot$ Limited liability $\cdot$ Private limited liability company $\cdot$ Public limited liability company $\cdot$ Firm

JEL Classification K 22

This article is dedicated to my beloved aunt Nurten Giray who passed away during the earlier stages of drafting this work.

Aslı E. Gürbüz Usluel

aslielif@bilkent.edu.tr

1 Bilkent University Faculty of Law, Ankara, Turkey 


\section{Introduction}

The purpose of company law is to increase social prosperity by raising the welfare of shareholders, employees, creditors, and other related third parties (Hansmann et al. 2009). Hence, legal orders regarding commercial companies are constructed to provide effective, express and easy company formation. Law makers on the other hand, have acted unconsciously towards a certain company type, namely the single member company (SMC), which was considered as being against legal theory in terms of contract formation in general and the company concept in particular. SMC can be defined as a limited liability company, which has a sole shareholder. SMCs can be classified into two groups. The first one is formed with a sole shareholder and the second one is the de facto SMCs which have only one real investor and one or more shareholders as nominal investors in order to meet a statutory requirement.

Criticisms regarding SMCs went so far that some lawyers have defined the concept as a "cancer of economic life" (Berg 1974: 935). ${ }^{1}$ Even though lawyers ignored the concept of SMC, economic needs in business gave rise to de facto solutions and the de facto SMCs became an indispensable and inevitable part of business activities in practice. Eventually, economic reality forced lawmakers to accept and regulate SMCs.

Most European jurisdictions have accepted the concept of SMCs as a legal entity and the European Union (EU) has adopted a directive specifically regulating SMCs. Accordingly, as an EU candidate country, Turkey harmonized its Turkish Commercial Code (TCC) in 2012 in accordance with EU regulations and introduced SMCs for the first time to the Turkish commercial law landscape. This article takes the SMC regulation in Turkey as its focal point and evaluates its impact in a comparative analysis looking at different jurisdictions and its economic effects after the enactment of the new TCC in 2012. In view of the fact that SMCs can only be formed as limited liability companies in Turkish law, this paper first examines the limited liability principle in commercial companies and sole proprietorship in the frame of the firm theory. After defining the principle of limited liability and its benefits for entrepreneurs, this article then evaluates SMC regulation in European jurisdictions and demonstrates the risks and benefits of the concept. Second, this article makes a comparative analysis between provisions of the new TCC and the EU directive demonstrating also the principles to avoid misuse and risk externalization in SMCs. The final section of this article examines data and statistics regarding commercial companies established in 2012 and 2013 and evaluates the economic impact of the new TCC regulation.

As all corporations, SMCs have the aim and effect of economizing transaction costs. Therefore, the purpose of this article is to demonstrate the transaction cost economy of SMCs in the light of the new provisions of TCC.

\footnotetext{
1 Main concerns of lawyers about SMCs were the organ formation and operation of company abuse. See Tekinalp (2013).
} 


\section{The concept of limited liability}

\subsection{Limited liability in commercial activities}

One of the best forms of establishing a business for an entrepreneur is to build a limited liability company, since it enables the entrepreneur to invest a small amount of equity and reduce risk through diversification ${ }^{2}$ and liquidate his investment quickly (Posner 2008). Moreover, conducting a business through a company allows entrepreneurs to transact easily through the medium of a corporate entity and thus lower the cost of business contracting (Halpern et al. 1980; Hansmann et al. 2009).

The concept of "limited liability" is necessity for entrepreneurs who desire to establish business through a company where they can be isolated from some of the risks of their commercial activity. ${ }^{3}$ Therefore, limited liability, as a valuable financing device, a contracting tool and universally accepted feature in terms of company formation should be defined and the reasons of choosing this concept should be explained at the outset.

Limited liability is defined as "defensive asset partitioning to distinguish it from the affirmative partitioning effects of the legal personality" (Hansmann et al. 2009: 385). When a company is incorporated with limited liability, shareholders commonly risk no more than their initial investment. In other words, if a company is incorporated with limited liability, the assets of the company provide guarantee to the company's creditors regarding the company's debts on the other hand, shareholders' personal assets are pledged as security to his personal creditors (Hansmann et al. 2009). As a result, when a company defaults on its obligations, the creditors can only claim the company's assets, but not the shareholders' personal assets. This does not necessarily mean that limited liability eliminates the risks of commercial activity failure, but shifting them from individual shareholders to creditors ${ }^{4}$ but this risk shifting comes at the price of a higher interest rate compared to an individual merchant, who is liable with all his personal assets. Therefore, this risk is internalized through high interest rates and as a result higher costs at the expense of shareholders, not at the expense of creditors. One may ask why would a shareholder wants to shift the downside risk of commercial activity failure to creditor, given that shareholder

\footnotetext{
${ }^{2}$ Since the investors invest their assets in a single firm, diversification is not a crucial consideration for closely held firms. For further information see Ribstein (1991).

3 In American law debt investors in sole proprietorship, general and limited partnerships, business trusts and other ventures possess limited liability. See Easterbrook and Fischel (1996). On the other hand, in Turkish law only the commercial companies can be subject to limited liability.

4 There are two kinds of creditors: voluntary and involuntary. Voluntary creditors are consumers, employees, trade creditors and lenders (Easterbrook and Fischel 1996). Involuntary creditors can be considered as tort victims and tax and regulatory authorities. Posner (2008), states that voluntary creditors are fully compensated by high interest rates, as a result of estimation of company default risk when the loan agreement signed. Defenders of the limited liability concept state that uncompensated transfers of risk of business failure from shareholders to creditors would occur on a substantial scale. Therefore, this would presumably restrict the availability of credit to limited liability companies and reduce the level of economic activity accordingly. For the historical evaluations and doctrinal discussions regarding limited liability see Halpern et al. (1980). Despite the assertions made by the defenders, consensus has been reached on the fact that limited liability aggregates the level of economic activity.
} 
must compensate creditor for bearing any additional risk (Posner 2008). There are some possible answers for this. ${ }^{5}$ On the one hand, the creditor could be a bank which is a specialist in the risk appraisal; therefore they are in a much better position to assess risk than a shareholder. In this case, it would be cheaper for a bank to appraise the risk. On the other hand, shareholders can be more risk averse than a bank when the corporate character of the banks are considered. ${ }^{6}$ Stated characteristics of limited liability, the complex nature of a modern economy and the risk accession increases the need for a limited liability regime. As a result, the reasons of highly utilizing limited liability can be evaluated in the light of the firm theory ${ }^{7}$ as follows:

First, agent monitoring increases the costs of companies. Agent is defined as " $a$ director or an officer or any person who is related to the corporation or who has directly or indirectly de facto control of the corporation ${ }^{8}$ " (Halpern et al. 1980: 123). Limited liability decreases the need to monitor agents, since it makes diversification and passivity a more rational strategy, it decreases the cost of operating the company (Easterbrook and Fischel 1996).

Second, limited liability decreases the cost of monitoring other shareholders (Halpern et al. 1980). In the case of unlimited liability, members of the company should control the other members' wealth since they are fully and severally liable for the company's debts. Therefore, members of an unlimited liability company should engage in costly monitoring of other members in order to avoid the risk of other member's asset transfer, which would risk his assets. However in limited liability, the identities of the shareholders are unrelated thus, it avoids all these costs (Easterbrook and Fischel 1996).

Third, a limited liability company's shareholders can freely transfer their shares. This is a crucial fact for the market in controlling the company, which serves an important purpose for a company's functioning ${ }^{9}$ (Manne 1967). When a company is run poorly, shareholders have the opportunity to sell their shares to a new group of investors who can install a new managerial team-since shares are tied to votes. To avoid possible future displacement, managers in a limited liability company would operate effectively to keep share prices high ${ }^{10}$ (Easterbrook and Fischel 1996). Undoubtedly, this evaluation can also be done for the publicly traded limited liability companies.

\footnotetext{
${ }^{5}$ For all possible answers stated in this article see Posner (2008).

${ }^{6}$ One should never overestimate the fact that, under some conditions, large shareholder might monitor the risk of company default better than a small trade creditor. The trade creditor on the other hand can protect himself by limiting the extension of credit to a short period (Posner 2008). These general characterizations of shareholders and corporate creditors are not universally true especially when unsophisticated creditors and employees who hold no diversified portfolios are likely to be more risk adverse and less able to appraise business risks than institutional shareholders. See Ribstein (1991: 101 fn. 92).

${ }^{7}$ The reasons why economic activities should be carried out in firms rather than individuals are illustrated in firm theory. For one of the first articles on this theory see Coase (1937).

${ }^{8}$ Three kinds of conflicts, conflicts between managers and shareholders, conflicts among shareholders and company's other constituencies are called by economists as agency problems (Hansmann et al. 2009).

${ }^{9}$ It is important to mention that, market for corporate control performs better for publicly held private companies.

${ }^{10}$ It should be stated that, unlike unlimited liability company, in limited liability shares are fungible and each share has its fixed market price. Therefore, there is no risk of being surcharged for an investor who wants to purchase shares.
} 
Fourth, limited liability allows isolating different kinds of businesses at the time of obtaining credit (Hansmann et al. 2009). By forming different kinds of companies as subsidiaries, each limited liability company would have different assets. Therefore, independent assets in a company group would be pledged as collateral security to creditors.

Fifth, limited liability shields the company from creditors of the owners. These creditors have access to the shares of an owner, but not to the assets of the company (Easterbrook and Fischel 1996). This is a decisive advantage over a partnership, which is always at risk that a creditor of a partner could seize assets of a company and threatens the business.

Finally, limited liability enables risk and return between equity holders and debt holders to be allocated in a more flexible manner, transaction costs of collection in case of insolvency are reduced and the pricing of stock are simplified. This significantly stabilizes the conduct of business in a company with limited liability (Hansmann et al. 2009).

Another way of doing business with the principle of limited liability is the sole proprietorship. This concept emerged as an alternative to SMCs and is considered to be an ideal model which satisfies the needs of entrepreneurs. However, it turned out to be an inefficient model for business activities. Indeed, an entrepreneur who wants to form a sole proprietorship with limited liability would associate his business assets into a separate pool in which he grants his business creditors priority over his personal creditors with respect to their claims (Hansmann and Kraakman 2000). Performing business with a limited liability company on the other hand allows asset separation by the help of existing legal rules. Nevertheless in the case of sole proprietorship, new legal rules should be enacted which are considered to be costly and time consuming in terms of law making procedure (Aydoğan 2012). Moreover, sole proprietorship conflicts with the legal principles that business enterprises have no legal entity and separate assets, and therefore owners are liable with their entire assets towards creditors. Creditors have an equal priority upon the entire assets of debtor and cannot simply change this rule by putting terms into contracts (Hansmann and Kraakman 2000). Yet, it is in the lawmaker's discretion to regulate sole proprietorship with separate assets (Aydoğan 2012).

\subsection{Single member companies as limited liability companies}

\subsubsection{SMCs in European jurisdictions}

Although the regulations regarding SMCs are recently introduced in some jurisdictions, de facto SMCs forms have been used for almost a century in USA, Europe and Turkey as a result of economic rationalism (Tekinalp 2013). In other words, economic necessities have forced jurisdictions to accept SMCs as a valid and legal entity. European jurisdictions can be considered as pioneers of the use of SMCs. Especially England and Lichtenstein have vital importance in the History of SMCs. Indeed, Solomon v. Solomon \& $\mathrm{Co}^{11}$ is the leading case in which de facto

${ }^{11}$ [1897] A.C. 22, H.L. See Davies (2012). 
SMCs were acknowledged in England (Davies 2012). In this decision House of Lords allowed incorporation of a company with a single member, although the Joint Stock Companies Act 1856 required the companies with limited liability to have at least seven members.

Today, legal provisions regulating SMCs in England have been enacted in Section 7 of the Companies Act 2006, which allows the formation of any company with a single person. Moreover, Lichtenstein is the first country where SMCs were explicitly allowed by the civil code of 1925. Many other jurisdictions did not regulate the formation of SMCs, but accepted SMCs emerged through concentration of all shares by a single shareholder. De facto SMCs existed in Germany in pre-war time (in the 1920s). The same was true for Polish law in the pre-war time. Over the years, the use of SMCs was expanded and legal systems were obliged to respond to the economic realities of SMCs. In this respect, Germany made one of the first radical reforms in the Limited Liability Company Act (GmbHG) in 1980 and allowed the formation of the SMC. According to the statistical analysis on the application of SMCs made in 1980- before the legal reform- $25 \%$ of the limited liability companies in Germany were established as de facto SMCs (Kreuzer 1980). This ratio however increased after the legal reform. It is stated that approximately $50 \%$ of one million limited liability companies in Germany are established as SMCs (Peifer 2008). In Europe, France followed Germany in 1985 and enacted SMCs in its Code Civil. ${ }^{12}$ The Netherlands (1986) and Belgium (1987) are the other European countries that allowed the formation of SMC. On the other hand, SMCs were not recognized in Spain, Greece, Ireland, the UK and Portugal prior to the directive (Werlauff 2003).

After EU member states started to accept the concept of SMCs in their jurisdictions, EU adopted the Twelve Company Law Directive ${ }^{13}$ in order to harmonize the use of single member private limited liability companies in the national laws of member states. The main goal of the directive is to create a legal instrument to enable individual entrepreneurs to limit their liability. ${ }^{14}$

The goals of setting up a SMC can be classified into three categories (Jocic 2005). First, to encourage small and medium size enterprises (SME) to be able form a SMC (Edwards 1998). According to the Commission, $94.4 \%$ of the microenterprises in the EU employ less than ten people and micro enterprises have larger contribution to employment than large businesses. ${ }^{15}$ In this regard, SMEs are the most appropriate form for SMCs. ${ }^{16}$ Second, to provide companies right of freedom in their establishment (Jocic 2005). Third, to disperse the assets of sole shareholder and the company (Power 1990).

\footnotetext{
12 For a detailed evaluation of French regulation of SMCs see Çevik (1998).

13 Twelfth Council Company Law Directive on Single Member Private Limited Liability Companies 89/667/EEC of 21 December 1989, Official Journal (OJ) L 395, 30.12.1989; This directive is changed by Directive 2009/102/EC of 16 September 2009, OJ L 258/20, 1.10.2009.

14 For a detailed study on the Directive see Çelik (2007).

15 White paper on growth, competitiveness and employment: The challenges and ways forward into the 21st century COM (94) 207 Final and COM (93) 700 Final.

16 See footnote 15 .
} 
According to the $2^{\text {nd }}$ article of the directive, formation of a SMC is defined as:

(1) A company may have a sole member when it is formed and also when all its shares come to be held by a single person (single-member company). Second paragraph of the same article states that: (2) Member States may, pending coordination of national laws relating to groups, lay down special provisions or sanctions for cases where: (a) a natural person is the sole member of several companies; (b) a single-member company or any other legal person is the sole member of a company.

Only private limited liability companies are intended to be covered by the directive. In article 6 of directive, it is recognized that member states could regulate single member public limited liability companies as well. If a member company regulates single member public limited liability companies then the provisions of the directive would apply. Moreover, the directive not only allows the formation of a single member private limited liability companies, but also permits member states to legislate limited liable individual entrepreneurs in article 7. This article is later named as lex Portugal, since Portugal was the only EU member state, which regulated the limited liability of the individual entrepreneur (E.I.R.L). Many economists and practitioners (Schwarz 2000) viewed the E.I.R.L as a poor application of limited liability regulation, and in 1997, Portugal eventually accepted the formation of single member private limited liability company without outright abolishing the E.I.R.L.

The targeted harmonization could not be achieved by the directive since it gave too much discretion to the member states (Jocic 2005; Eroğlu 2008). Indeed, the directive does not address very important issues, such as creditors' protection, minimum capital requirements, transfer of seat, registration requirements and dissolution and left them to the regulation at a national level. ${ }^{17}$ On the other hand, the directive at least allows all member states to regulate SMCs.

After the regulation of EU Twelfth Directive, SMEs started to play even more important role in strengthening the EU economy. The Commission's annual report on SMEs estimates that in 2012 there were around 20,7 million SMEs in the EU. This constitutes more than $98 \%$ of all enterprises. SMEs accounted for $67 \%$ of total EU employment and for $58 \%$ of EU gross value added. ${ }^{18}$

On the other hand, due to the diversity of national company laws, establishing a subsidiary abroad involves costs of meeting legal and administrative requirements, for instance, necessary legal advice and translation costs in other countries, which are frequently different in companies' home country. Those costs are likely to be particularly high for groups of companies since any SME parent company is faced

\footnotetext{
${ }_{17}$ European Commission, Roadmap, Single member Company, DG MARKT/F2, 03/2013, available at http://ec.europa.eu/smartregulation/impact/planned_ia/docs/2014_markt_003_single_member_company. pdf (accessed on 15 October 2014).

18 The report "EU SMEs in 2012: at the crossroads. Annual report on small and medium-sized enterprises in the EU", 2011/12, available at http://ec.europa.eu/enterprise/policies/sme/facts-figuresanalysis/performance-review/files/supporting-documents/2012/annual-report_en.pdf. (accessed on 23 January 2015).
} 
with different requirements for each subsidiary it tries to establish in another Member State. ${ }^{19}$

According the consultation on SMCs in the 2013, $74 \%$ of companies and business federations considered that the harmonization of rules for single-member private limited liability companies could facilitate cross-border activities of SMEs. $^{20}$ Consequently, the European Commission drafted the proposal for Directive on Single Member Limited Liability Companies, which leads member states to harmonize their national laws accordingly.

The new proposal simplifies the single member limited liability company formation by allowing on-line registration (Art. 14) with a uniform template of articles of association in all member states (Art. 11), reducing the minimum capital requirement to $€ 1$ (Art. 16) accompanied by balance sheet solvency statement and regulating director's liability ${ }^{21}$ (Art. 22). These provisions of proposal would diminish set-up and operational costs. According to the estimates stated in the impact assessment, ${ }^{22}$ the cost reduction for the founders of single-member private limited liability companies in 1 year in the EU could range from $€ 236$ to 653 million.

Moreover, creditors are strictly protected by the restrictions on the distributions, and all SM private limited liability companies have to use the EU-wide abbreviation in their trade name SUP (Societas Unius Personae), which would secure the transactions between company and the third parties by increasing the awareness of third parties on the company type.

Although on-line registration system would increase the costs for the EU member states, it is stated in the impact assessment that, costs would be one-off versus the resulting permanent benefits for companies. ${ }^{23}$

\subsubsection{Benefits of SMCs}

Prior to its acceptance in most of the jurisdictions, de facto SMCs were established in order to benefit from the economic advantages of this company type. In Turkey, to comply with the statutory requirements on the minimum number of shareholders, most investors formed de facto SMCs through their family members. ${ }^{24}$ However, as a result of conflicts among family members given the lack of professionalism and governance, such companies did not last long. Therefore, acceptance of SMCs as a legal entity legitimizes the existence of de facto SMCs and helped to make the life of the companies longer (Eroğlu 2008).

SMCs generate potential monitoring economies for the firm owners. ${ }^{25}$ In a SMC form, the shareholder does not need to select fellow shareholders having similar

\footnotetext{
${ }^{19}$ European Commission Staff Working Document Impact Assesment, COM (2014) 212.

${ }^{20}$ COM (2014) 212.

21 For an analysis of director's liability in listed firms using modern finance theory see Rose (2011).

22 See COM (2014) 212.

23 COM (2014) 212.

${ }^{24}$ For ownership characteristics of different countries see Marinov and Heiman (1998).

25 For limited liability companies see Hansmann and Kraakman (2000).
} 
assets and risk preferences. Therefore, the single shareholder will not face negotiating costs (Hansmann and Kraakman 2000). Since he would not have to investigate the other possible future shareholders and face negotiating costs, his information costs would be reduced. For that reason, SMCs serve as a great instrument for institutions such as universities, foundations, societies, state owned enterprises, which need to establish a company in order to provide a fund to accomplish their purpose. For example, a university or a foundation can form a limited liability company and transfer revenues of the company to the university or foundation budget to provide qualified education for a university or satisfy the goal of the foundation. However, formation of limited liability companies by these institutions with multiple shareholders might conflict with their characteristics and the interest that they represent (Lindemann 1996; Eisenhardt 2003; Tekinalp 2007; Aydoğan 2012). Therefore, the best way to supply funds to these institutions with reduced information and negotiating costs is with the establishment of SMCs.

Similarly, the globalized economy in the world forces countries to have wellfunctioning and competitive commercial laws in order to compete with other countries in order to attract foreign direct investment and encourage entrepreneurs to participate in business (Eroğlu 2008). SMCs are one of the best ways for a foreign investor who requires entering individually into a new market in which he does not know the market conditions and legal rules of the country. A foreign investor would not have to search for a partner in the country with unknown market conditions or in the cases where he finds the right partner, he does not have to bargain for the partner's contribution to the firm.

SMCs provide a great advantage not only for foreign investors, but also for sole entrepreneurs who want to enter into the market alone, but intend to go public after a certain period of time. Since there is an existing company, without investing on the formation of another new company and reducing transaction costs, single member public limited liability companies can easily go public by offering its shares (Tekinalp 2013), which increases the efficiency of the market.

Due to their corporate character, SMCs allow the transfer of all company assets in a single legal transaction, which decreases transaction costs (Tekinalp 2007). In most of the continental European law jurisdictions, in the cases of mergers, divisions and acquisitions, assets of the company (multiple or single member) are transferred to another company with a single contract, which is registered to the trade registry. In other words, there is no need to apply the form requirement to transfer the rights on each item in the company assets which increases the efficiency in the establishment procedure by reducing the costs of registration and announcement in a trade registry.

Moreover, SMCs are the practical form for affiliated companies (Atabek 1987; Wooldridge 2001). For example, a company in the oil sector can establish three different SMCs for oil production, manufacturing and marketing respectively (Aydoğan 2012). In the case of a default, each company would be liable for the company debts with its own assets. Since SMCs prevent potential conflicts, such as protection of minority shareholders in the company group structure and this increases the business efficiency, SMCs are the essential instruments in the formation of $100 \%$ owned **subsidiaries (Forstmoser et al. 1996). 
It is important to note that the relation between efficiency and size of the firm is one of the most serious problems of firm theory. Single shareholder reduces the governance costs by decreasing decision-making, hierarchy cost of the firm. ${ }^{26}$ This fact is crucial when the sole shareholder and the sole board member are the same natural or legal person. It does not only facilitate the terms of decision making, but also reduces the agency costs since conflicts between managers and shareholders and conflicts among shareholders can not arise. Moreover, separation of ownership and control principle accepted in limited liability doctrine creates asymmetric information problem, which results in the shareholders lack of knowledge regarding the management for the firm. However, the SMCs asymmetric information problem does not occur when the sole owner and sole manager are the same persons.

Considering the benefits of SMCs, it is important to regulate it as a legal entity to increase rates of development in national economies by allowing the formation of more firms. ${ }^{27}$ However, they might carry some risks for the shareholder and the creditors.

\subsubsection{Risks of SMCs}

Despite the many advantages of SMCs, they also carry potential risks, which could lead to an abuse of creditor's rights. There is a possibility that a sole member's assets and the assets of the company gets mixed up, which could end up shifting the shareholder's debts to the SMC. Moreover, since there is only one shareholder for the supervision and observation of the organs and managers of SMCs, in case of an infringement, the cost of occurred damage might increase (Tekinalp 2013).

The information costs are high in unlimited liability companies, because of the liability of the company members. Creditors need to monitor the members' assets and members also monitor themselves. However, in small and closely held limited liability companies, such as SMCs, the difference in information costs between limited and unlimited liability firms might be small due the fact that their creditors often require personal guaranties, which sometimes increases the transaction costs (Halpern et al. 1980). In order to protect their investment, creditors might be willing to be informed of any changes in the firm and this can only be done in monitoring activities (Halpern et al. 1980).

One of the risks that small firms, such as SMCs, bear is that incorporation of limited liability sometimes cannot allocate risk that in the long run weakens the firm and favors the creditors (Freedman 2000). Furthermore, under certain circumstances limited liability cannot reduce the transaction and monitoring costs. In some respects, the apparent existence of limited liability adds costs, such as cost of disclosure $^{28}$ (Freedman 2000).

\footnotetext{
${ }^{26}$ Regarding the cost of bureaucracy see Williamson (1985).

27 According to Williamson (1985: 154) the major benefit of integration derives from the fact that party with the authority in a firm can resolve disputes without litigation but by decision making. It is quite difficult to agree with this statement from a legal point of view since in some cases decision making would not be easy even though the majority principle is accepted. Moreover directors carry the burden of personal liability because of the decisions they have made.

28 For mandatory accounting disclosure by small private companies see Arrunada (2011).
} 
Although SMCs engender risks in their functioning, the cost and benefit analysis demonstrates that their benefits prevail over risks considering the fact that risks can be precluded by accepting some safeguards, such as piercing the corporate veil.

\subsubsection{Principles regarding SMC and safeguards against misuse and externality of risks}

2.2.4.1 Piercing the corporate veil When the principle of separation of assets is breached, the sanction of this infringement would be piercing the corporate veil. ${ }^{29}$ Under some circumstances, the company's veil is pierced or lifted to abolish limited liability in favor of creditors. By piercing the corporate veil, creditors can claim shareholder's assets in case of a SMC's - or any type of company-default. Piercing the corporate veil has no statutory basis in Turkey and corporate veil can be pierced only in exceptional cases by courts. When a shareholder enjoys the assets of a company as if the assets belong to him, accepts the credit returns of the company, yields to bankruptcy of the company and plunges company into debt, in short, in situations such as this where the company is used for an illegal or improper aim, the veil may be pierced by the courts (Tekinalp 2013). In most of the jurisdictions courts give their decisions according to the facts of that particular case.

From the economic point of view, in most of the jurisdictions courts will pierce the veil when a SMC cannot efficiently improve the liquidity and diversification, and most probably engages in socially excessive level of risk taking. ${ }^{30}$ Misrepresentation is the one of the basic basis for the courts to pierce the corporate veil. In the cases of misrepresentation, creditors cannot foresee the actual default position of the company and cannot assess the risk of default. Therefore, misrepresentation would increase the information costs for creditors (Posner 2008).

Courts might be willing to pierce the veil in SMCs more than publicly held corporations (Easterbrook and Fischel 1996). The reason is that in SMCs, the management and the risk bearing is less separated. Since in SMCs manager shareholder's liability is limited to the company assets, they transfer more risk to the third parties. Therefore, piercing the corporate veil reduces the costs that third parties bear.

Most of the piercing the corporate veil cases arise from parent subsidiary combinations. Parent companies can form subsidiaries to engage in risky activities with minimum capital. In cases where the company runs well, the parent company can earn a profit. On the other hand, when a company unsuccessful, the subsidiary may declare bankruptcy and the parent company may form another subsidiary with the same managers. ${ }^{31}$ As Easterbrook and Fischel (1996: 57) states: "this asymmetry between benefits and costs, if the limited liability is absolute, would create

\footnotetext{
29 See Farrar (1990); Payne (1997); Thomson (1990-1991). For Turkish Law see Tekinalp and Tekinalp 1995; Dural 1998; Yanl1 2000; Seven and Göksoy (2006); Suits that are related to Veil Piercing in Turkish law see Tekinalp (2013).

30 Almost every US cases where veil is pierced, involved a close corporation. See Easterbrook and Fischel (1996).

31 For the example see Easterbrook and Fischel (1996); see also Posner (2008).
} 
incentives to engage in a socially excessive amount of risky activities." Therefore, courts would pierce the corporate veil if such cases occur in corporate groups.

Undercapitalization is an important factor for veil piercing decisions, which rely on the similar basis. When the capital of a company is low, the probability of risky activities is higher (Easterbrook and Fischel 1996). In the situation of undercapitalization, disclosing information about the company's unusual capitalization to creditors is crucial. The reason is that sometimes creditors do not investigate the company's financial situation, because some transactions are too small in value. When the company is undercapitalized, piercing the corporate veil threat might motivate the company to disclose relevant information at the time of the transaction. Creditors can free to decide on the transaction. In turn, the debtor has to pay for employing these risky activities (Easterbrook and Fischel 1996).

In Turkish law, there is no specific provision regulating a rule that permits courts to pierce the corporate veil. Besides the economic basis with respect to the facts of the case, the general principles of Turkish Civil and Commercial Codes would be applied **(Tekinalp and Tekinalp 1995; Yanl1 2000). In the case of misuse of the legal personality, breach of good faith rules would be applied in Turkish Law. ${ }^{32}$ The legal cases in which the company's veil is pierced are rare. ${ }^{33}$ By acknowledging the concept of SMCs in the Turkish system, we assume that the number of cases in which the piercing the corporate veil doctrine is applied will increase.

2.2.4.2 Principle of separation of assets Separation of assets, which is one of the characteristics of limited liability, avoids the mix up of assets in the company and acts as a safeguard against the misuse of SMCs. Separation principle provides absolute separation of the legal personality of the company and the shareholder, diverges assets and allow the two different personalities being totally separate while enjoying rights and being subject to obligations (Tekinalp 2007, 2013). Therefore, creditors of the company cannot claim on shareholder's assets and shareholder's personal creditors nor claim on company's assets, if there is a lack of legal basis for the application of piercing the corporate veil doctrine. Since the creditors can only claim assets of their own debtors, separation of assets principle allocates risk in SMCs and reduces the transaction costs in the case of bankruptcy. ${ }^{34}$

\subsubsection{Principle of prohibition against loans to the shareholders by compa-} nies The prohibition against loans to shareholders by companies reduces the chance of misuse of SMCs by creating a virtual wall between the assets of company and assets of shareholders. This principle is regulated in TCC both for public and private limited liability companies (TCC Art. 358 and 644). Therefore, according to

\footnotetext{
32 According to Art. 2 of Turkish Civil Code "every person is bound to exercise his rights and fulfill his obligations according to the principles of good faith." Therefore judges would decide if there is a misuse or not accordingly. For the translation of this article see Eroğlu (2008: 1282).

33 For some of the important cases with respect to piercing the corporate veil doctrine in Turkish law see. Supreme Court 19. HD., 2.11.2000, E. 2000/5828, K. 2000/7383; Supreme Court 19. HD., 15.6.2006 E. 2005/8774, K. 2006/5232; Supreme Court 11. HD, 5.4.2012, E. 2010/14261, K. 2012/5407 available at http://kazanci.com (accessed on 13.02.2014).

34 For same approach in limited liability principle see Hansmann et al. (2009).
} 
these provisions shareholders or members of the company may not be indebted to the company if the shareholder does not fulfill its due obligations arising from capital payment and the company's profit, including the free reserves is not sufficient to recoup the losses from previous years. This principle serves as a great instrument to avoid misuse in SMCs.

2.2.4.4 Minimum capital requirement Although minimum capital requirement has some disadvantages such as administrative costs in determining the amount of capital that firms should raise and cost error in situations where the capital requirement sat so high that it blocks companies to enter into the market and allows the existing firms charge monopoly prices (Easterbrook and Fischel 1996), the minimum capital requirement guarantees the amount of capital of SMCs and can be considered as a method of internalizing the costs of risk taking.

The minimum capital requirements set forth in TCC for public limited companies is 50.000 TRL for the equity capital and 100.000 TRL for the authorized capital according to the Art. 332 of TCC. For the private limited liability companies, the minimum capital requirement is 10.000 TRL. In some jurisdictions, a system that provides guarantee for the capital contribution in SMCs is regulated. ${ }^{35}$ However, in order to encourage the formation of SMCs that are effective instruments for the economy and social welfare, additional conditions that restrain the establishment of SMCs should not be included in the regulations.

\section{The regulation of SMCs in Turkish law and its consequences}

\subsection{Basic provisions of the Turkish Commercial Code}

The new TCC that entered into force in July 2012 has reformist provisions mostly regarding company law. One of the most significant and novel provisions for Turkish company law is the provision with respect to SMCs. Before the provisions regulating SMCs were put into force, de facto SMCs existed in practice where most of the shares were concentrated by one real shareholder the other small amount of shares were distributed among passive shareholders to comply with the number of minimum number of shareholder requirement.

SMCs are introduced in the Turkish legal system with the new TCC and the new TCC allows the establishment of those in the form of either private or public limited liability companies. Therefore, legal personality and limited liability are the two basic characteristics of SMCs. TCC Art. 573 allows the establishment of single member (SM) private limited liability companies and in the reasoning, it is stated that the provisions of EU Twelfth Directive are mostly taken as a basis during the drafting of this article. However, it is also pointed out in the reasoning that Art. 573 aimed not only to harmonize national laws with that of EU, but also to prevent the misuse arising from the de facto SM private limited liability companies.

\footnotetext{
35 In favor of this system see Eroğlu (2008).
} 
Art. 338 of TCC details the requirements of SM public limited liability companies and in the reasoning it is stated that EU Twelfth Directive's approach towards SMCs is reflected in this article. Moreover, the article's reasoning explains the benefits of SM public limited liability companies and states that they facilitate the formation of group of companies since they are the best instruments in establishing subsidiaries, support the governance of companies, simplify the establishment of foundation enterprises, and prevent the family companies from dissolution.

The first paragraph of Art. 338 of TCC prescribes SMCs that are formed ab initio with one member. The second paragraph, however, regulates the SMCs that are not initially constituted with one member, but became SMC by virtue of all of the shares being vested in one shareholder. The second paragraph also states the publicity requirement, which states the fact that board of directors need to be notified in writing, in 7 days after transactions that vest shares in one shareholder. Furthermore, after the board of directors receives the written notification, they are entitled to register the fact that the company became a SMC in the Turkish Trade Registry and announce this fact in the Turkish Trade Registry Gazette within 7 days. Similar requirement regulated for SM private limited liability companies in Art. 573/2 TCC which is a parallel provision to the Art. 3 of the Directive.

A natural or a legal person could form either a public and private SMC (Art. 338 and 553). On the other hand, TCC has no parallel provision to Directive Art. 2, which reserves a member state a right to lay down special provisions or sanctions against natural persons who are the sole member of a company. The only restriction is that the company cannot acquire its shares in a way that the acquisition grants him the status of sole shareholder.

Regarding decision taking, TCC Art. 408/3 and 616/3 provide specific provisions related to this subject. According to these provisions, a sole shareholder in either public or private limited liability companies is authorized to take decisions for the company. In other words, shareholder exercises the powers of general meeting of the SMCs. These decisions should be drawn up in writing and comply with the Art. 5 of the Directive.

With respect to transactions between the member and the company, the written requirement is stated in the 5th Art. of the Directive and also in TCC Art. 629/2 and $371 / 6$ for SM public and private limited liability companies respectively. According to the provisions of the TCC, contracts between a sole member and his company, as either represented by him or not, would be drawn up in writing. These provisions do not apply to contracts that are deemed to be unimportant and ordinary according to the market conditions. Although Art. 5 of the Directive and TCC resemble each other, the TCC has regulated the written requirement rule in an extended scope (Çelik 2007). First, according to the provision of TCC, a sole member does not necessarily represent the company for the written requirement. Second, this requirement is a form of contract validity.

It should be indicated that, third parties would have been more effectively protected if a provision which imposes an obligation to state "SM" in the trade name and company documents were regulated in the TCC (Çelik 2007). Moreover, sole shareholder's liability is not specifically regulated in Turkish law and as a result disputes may arise especially when the sole shareholder also acts as a company 
manager. A possible resolution might be the application of general provisions regarding the manager liability under the TCC.

The European Commission's proposal provides solutions to the criticisms that are indicated above by regulating the obligation to indicate the abbreviation SUP in the trade name and the liability of directors and single members of SMC. As a candidate country to the EU, Turkey should harmonize its legislation according to the provisions of the proposal after it is put into force as a directive internally. However, the harmonization process will be introducing costs for the Turkish economy regarding on-line registration process, since infrastructure of digital registration system has not been established in Turkey. The formation of public and private limited liability companies are accomplished by the registration of articles of association to the trade registry (TCC Art. 354 and 587). Moreover, changing provisions of TCC regarding the minimum capital requirement (Art. 332, 580), which secures the creditors, articles of association (Art. 576 and 339) would increase the law making cost. However, simplification of SMCs' formation over all would increase the effectiveness of the application of this company model.

\subsection{Expectations and evaluations}

De facto SMCs have been the solution to the economic necessities until the enactment of the new TCC that allows for the establishment of public and private limited liability companies as SMCs. TCC entered into force in July 2012 and for almost 2 years, the provisions of TCC have been applied. An important question can be raised at this point: what is the outcome of new TCC with respect to limited liability companies and SMCs?

The new TCC includes reformist provisions regarding public disclosure requirements particularly for limited liability companies that obviously reduce transaction costs. According to Art. 1527 of TCC, public limited liability companies which are subject to independent audit should develop a website and put up all the relevant documents online that they are under a duty to disclose. In the draft TCC, this article was regulated differently and all companies with limited liability were under the obligation to develop a website and publish all documents that they have in this website. Before the amendment, the article was definitely drafted to reduce information costs and was in compliance with the European regulations.

Moreover, the new TCC increases the relevant documents or events that are to be registered in the trade registry. Indeed, this accretion will increase the administrative costs for companies and make the establishment of companies more difficult. However, the statistics below shows the apparent results to be positive with respect to the Turkish economy in general and the company formation in particular.

In the third quarter of 2013, the Gross Domestic Product in current prices was 619,303 million USD and in constant prices 91,219 million TRL. Moreover, the Turkish economy grew by $4.4 \%$ expanding by $4.0 \%$ in the first three quarters of $2013 .^{36}$

\footnotetext{
${ }^{36}$ Report on Turkish Economy, Ministry of Customs and Trade, 13 February 2014, Available at http:// risk.gtb.gov.tr/data/52c2bb03487c8e312c013182/T\%C3\%9CRK\%C4\%B0YE\%20EKONOM\%C4\% B0S\%C4\%B0\%20G\%C3\%96STERGELER\%C4\%B0_2014_02_13.pdf (accessed on 13.02.2014).
} 
Table 1 Company establishments according to company types in 2013

\begin{tabular}{|c|c|c|c|c|c|c|}
\hline & \multicolumn{5}{|c|}{ Company types } & \multirow[t]{2}{*}{ Total sum } \\
\hline & $\begin{array}{l}\text { Public } \\
\text { limited } \\
\text { liability }\end{array}$ & $\begin{array}{l}\text { General } \\
\text { partnership }\end{array}$ & $\begin{array}{l}\text { Limited } \\
\text { partnership }\end{array}$ & $\begin{array}{l}\text { Private } \\
\text { limited } \\
\text { liability }\end{array}$ & Cooperatives & \\
\hline \multicolumn{7}{|l|}{ January-October } \\
\hline Number & 6.951 & 35 & 2 & 33.097 & 791 & 40.877 \\
\hline $\begin{array}{r}\text { Equity Capital } \\
\text { (million TL) }\end{array}$ & 5880.9 & 4.5 & 0.1 & 3826.1 & - & 9711.7 \\
\hline \multicolumn{7}{|l|}{ November } \\
\hline Number & 892 & 1 & 0 & 3.755 & 67 & 4.715 \\
\hline $\begin{array}{r}\text { Equity Capital } \\
\text { (million TL) }\end{array}$ & 1354.3 & 0.02 & 0 & 413.1 & - & 767.4 \\
\hline \multicolumn{7}{|l|}{ December } \\
\hline Number & 860 & 0 & 0 & 3.435 & 56 & 4.351 \\
\hline $\begin{array}{r}\text { Equity Capital } \\
\text { (million TL) }\end{array}$ & 836.7 & 0 & 0 & 406.9 & - & 1243.5 \\
\hline \multicolumn{7}{|l|}{ SUM } \\
\hline Number & 8.703 & 36 & 2 & 40.287 & 915 & 49.943 \\
\hline $\begin{array}{l}\text { Capital } \\
\quad \text { (million TL) }\end{array}$ & 8071.9 & 4.5 & 0.1 & 4691.1 & - & $12,767.6$ \\
\hline
\end{tabular}

This chart illustrates the numbers of companies and the capital vested in all kinds of commercial companies in Turkey

TOBB, 2013 Aralık Ayına Ait Kurulan ve Kapanan Şirket İstatistikleri Haber Bülteni, 24 Ocak 2014, No. 2013/12, p.1

Most importantly, foreign direct investment in the third quarter of 2013 reached 7409 million dollars in Turkey. According to the statistics of Turkish Ministry of Customs and Trade $2013,{ }^{37} 3.875$ public and private limited liability companies were established with foreign capital. Foreign investors preferred public limited liability companies rather than private. Indeed the number of public companies with foreign capital was 496 and the number increased to 801 in 2013.

Moreover, in 2013, the number of active commercial companies increased by $3.46 \%$ and reached to 972.491 . The $81.5 \%$ of which were private limited companies and $11 \%$ public limited liability companies.

It is noteworthy to mention that in 2012 when the former TCC was in force, the number of established companies was 39.764, however, in 2013, this number increased $25.6 \%$ to 49.943 and the number of public limited liability company increased by $111.4 \%$ which is drastic (Table 1$).^{38}$

\footnotetext{
37 Available at http://risk.gtb.gov.tr/data/52c2bb03487c8e312c013182/T\%C3\%9CRK\%C4\%B0YE\% 20EKONOM\%C4\%B0S\%C4\%B0\%20G\%C3\%96STERGELER\%C4\%B0_2014_02_13.pdf (accessed on 13.02.2014).

38 See press release of Hayati Yazici, Minister of Customs and Trade available at http://www.gtb.gov.tr/ haberler/yazici-yeni-turk-ticaret-kanunu-uygulama-sonuclarini-basin-toplantisinda-acikladi (accessed on 13.02.2014).
} 
According to the statistics, entrepreneurs preferred to establish more limited liability companies and especially public limited liability companies in Turkey. In addition, foreign direct investment increased, mostly from EU member states. ${ }^{39}$ Therefore, the new TCC, especially the new provisions regarding the commercial companies efficiently affected Turkish markets. Limited liability companies increase in value. Although the number of limited liability companies is certain in number, SMCs are not, it can be easily assumed that in the drastic increase in the number of limited liability companies, the regulation of SMCs as legal entities have undeniable role.

\section{Conclusion}

Although the concept of a SMC has been criticized by plenty of lawyers around the world, it has been accepted by economic actors for a long time and the concept has now been accepted in many jurisdictions around the world.

With the recognition of SMCs, existing de facto SMCs are legitimized and by elimination of other possible conflicting shareholders, it is observed that the average life of these companies will be prolonged. SMCs reduce the information costs so that some institutions such as universities, societies and foundations are able to establish a company in order to provide funds to achieve their purpose. SMCs provide great advantages for entrepreneurs who want to enter the market alone. Another advantage of commercial companies in general and SMCs in particular, is the ability to transfer of all company assets in a single legal transaction, which decreases the transaction costs. In addition, SMCs are the best models for attracting foreign direct investment. On the other hand, the breach of "separation of capital of the company and the management" principle and the possibility of asset mix up are the risks that they bear.

To avoid the misuse of SMCs, some principles should be accepted and regulated such as separation of assets, the doctrine of piercing the corporate veil, prohibition on loans to the shareholders by companies, and the minimum capital requirements in legal systems. In some jurisdictions, a system that provides guarantee for the capital contribution in SMCs is regulated. However, in order to encourage the formation of SMCs additional conditions that restrain the establishment of SMCs should not be included in regulations.

As an EU candidate country, Turkey harmonized its TCC in 2012 in accordance with EU regulations and introduced SMCs for the first time to Turkish commercial law. All provisions with respect to SMCs are in accordance with Twelfth Directive of EU; however, provisions regarding publicity and sole shareholder liability could have been regulated more specifically.

Data and statistics regarding the number of commercial companies established in 2012 and 2013 illustrate that the number of limited liability companies has

\footnotetext{
39 Available at http://risk.gtb.gov.tr/data/52c2bb03487c8e312c013182/T\%C3\%9CRK\%C4\%B0YE\% 20EKONOM\%C4\%B0S\%C4\%B0\%20G\%C3\%96STERGELER\%C4\%B0_2014_02_13.pdf (accessed on 13.02.2014).
} 
drastically increased and Turkey has become an attractive country for the foreign direct investment. Therefore, the TCC and provisions regarding SMCs have had an explicit and positive effect on the Turkish economy.

\section{Compliance with ethical standards}

Conflicts of interest The author declares that she has no conflict of interest.

Human and animal rights statement This article does not contain any studies with human participants or animals performed by the author.

\section{References}

Arrunada, B. (2011). Mandatory accounting disclosure by small private companies. European Journal of Law and Economics, 32, 377-413.

Atabek, R. (1987). Tek Ortaklı Şirket. Batider, XIV(1), 23-35.

Aydoğan F. (2012). Tek Kişi Ortaklı̆̆ . Vedat Publishing.

Berg, H. (1974). Schadensersatzanspruch des GmbH-Alleingesellschafters bei einem Schaden der Gesellschaft. In NJW, pp. 933-935.

Çelik, F. H. Ş. (2007). Hukukun Ekonomik Gerçekliğe Yanıtı: Tek Kişilik Şirketler. Batider, XXIV(1), $161-216$.

Çevik, K. (1998). Fransız ve Türk Hukukunda Tek Ortaklı Şirket/Sınırlı Sorumlu İşletme, Prof.Dr. Ali Bozer'e Armă̆an, Banka ve Ticaret Hukuku Araştırma Enstitüsü, 37-55.

Coase, R. H. (1937). The nature of the firm. Economica, 4, 386-405.

Davies, P., \& Worthington, S. (2012). Gower's principles of modern company law. London: Sweet \& Maxwell.

Dural, M. (1998). Tüzel Kişilik Perdesinin Aralanması, SPK 15. Yıl Sempozyumu.

Easterbrook, F. H., \& Fischel, D. R. (1996). The economic structure of corporate law. Cambridge: Harvard University Press.

Edwards, V. (1998). The EU twelfth company law directive. Company Lawyer, 7, 211. et seq.

Eisenhardt, U. (2003). Gesellschaftrecht. Munich: Verlag C. H. Beck.

Eroğlu, M. (2008). Single member companies in Turkish law. Legal Hukuk Dergisi, 64, 1269-1281.

Farrar, J. (1990). Fraud, fairness and the piercing the corporate veil. Canadian Business Law Journal, 16, 474-502.

Forstmoser, P., Meier-Hayoz, A., \& Nobel, P. (1996). Schweizerisches Aktienrecht. Bern: Stämpfli Verlag.

Freedman, J. (2000). Limited liability: large company theory and small firms. The Modern Law Review, 63, 317-354.

Halpern, P., Trebilcock, M., \& Turnbull, S. (1980). An economic analysis of limited liability in corporation law. University of Toronto Law Journal, 30, 117-150.

Hansmann, H., \& Kraakman, R. R. (2000). The essential role of organizational law. Yale Law Journal, $110,387-440$.

Hansmann, H., Kraakman, R. R., et al. (2009). The anatomy of corporate law: A comparative and functional research. Oxford: Oxford University Press.

Jocic, D. R. (2005). A single member company-Convenient or not for the founders. Facta Universitatis, Economics and Organization, 2(3), 209-219.

Kreuzer, K. (1980). Die Glaeubigerschutzbestimmungen der GmbH-Novelle für die Einmann-GmbH und die GmbH u. Co. Zeitschrift für Wirtschaftsrecht, 9, 722-726.

Lindemann, B. S. (1996). Die Beschlussfassung in der Einmann-GmbH: eine Studie über das Zustandekommen des Beschlusses in der Einmann-GmbH und über die Rechtsfolgen beim fehlerhaften Einmannbeschluss. Heidelberg: Decker Verlag.

Manne, H. J. (1967). Our two corporation systems: Law and economics. Virginia Law Review, 53, 259-284. 
Marinov, B. Z., \& Heiman, B. A. (1998). Company law and corporate governance renewal in transition economies: The Bulgarian dilemma. European Journal of Law and Economics, 6, 231-261.

Payne, J. (1997). Lifting the corporate veil: Lifting the fraud exception. Cambridge Law Journal, 56, 284-290.

Peifer, M. (2008). Die Pflichtenstellung des Alleingeselschafters gegenüber der GmbH. GmbHRundschau, 20, 1074-1078.

Posner, R. (2008). Economic analysis of law. Alphen aan den Rijn: Aspen Law \& Business.

Power, V. J. G. (1990). Twelfth EC company law directive. ICCLR, 1, 44. et seq.

Ribstein, L. E. (1991). Limited liability and theories of corporation. Maryland Law Review, 50, 80-130.

Rose, C. (2011). Director's liability and investor protection: A law and finance perspective. European Journal of Law and Economics, 31, 287-305.

Schwarz, G. C. (2000). Europaeisches Gesellschaftsrecht. Baden-Baden: Nomos Verlagsgesellschaft.

Seven, V., \& Göksoy, C. Y. (2006). Ticaret Şirketlerinde Tüzel Kişilik Perdesinin Kaldırılması. İstanbul Barosu Dergisi, 80(6), 2455-2471.

Tekinalp, G. \& Tekinalp Ü. (1995) Perdeyi Kaldırma Teorisi. In Reha Poroy’a Armă̆an, pp. 387-404.

Tekinalp, Ü. (2007). Tarihi Gelişim İçinde Tek Ortaklı Şirketler Sorunsalı ve Türk Hukukunun Bu Konudaki Aç1lımı. Dr.Hüseyin Ülgen'e Armă̆an, 1, 509-579.

Tekinalp, Ü. (2013). Sermaye Ortakliklarının Yeni Hukuku. Vedat Publishing.

Thompson, R. B. (1990-1991). Piercing the corporate veil: An empirical study. Cornell Law Review, 76, 1036-1074.

Werlauff, E. (2003). EU-company law, common business law of 28 states. Copenhagen: Djoef Publishing. Willamson, O. (1985). Economic institutions of capitalism. New York: The Free Press.

Woodward, S. (1980). Limited liability in the theory of firm. Journal of Institutional and Theoretical Economics, 141, 601-611.

Wooldridge, F. (2001). A simplified legal regime for small and medium-sized German public companies. Company Lawyer, 22, 27-30.

Yanlı, V. (2000). Anonim Ortaklıklarda Tüzel Kişilik Perdesinin Kaldırllması ve Pay Sahiplerinin Ortaklık Alacaklılarına Karşı Sorumlu Tutulması. Beta Publishing. 